\title{
Inovasi Media Edukasi Bahasa Arab
}

\author{
Mohammad Zumrodi ${ }^{*}$, Agung Riyantomo² \\ ${ }^{1,2}$ Jurusan Teknik Informatika, Fakultas Teknik, Universitas Wahid Hasyim \\ Jl.Menoreh tengah X/22, Sampangan Semarang 50236 \\ *Email: zumzum089@gmail.com
}

\begin{abstract}
Abstrak
Bahasa arab merupakan mata pelajaran sekolah dasar / madrasah ibtidaiyah, salah satu poin dari mata pelajaran ini yaitu kalimat fi'liyyah. Guru mengajarkan dengan metode konvensional. Pada sekolah MI Nyatnyono 01, masih minim sekali akan media pembelajaran sebagai alternatif belajar. Berdasarkan permasalahan tersebut, penulis membuat sebuah aplikasi media baru untuk mempermudah siswa dalam belajar materi kalimat fi'liyyah. Penulis menggunakan metode pengembangan Multimedia Development Life Cycle yang memiliki 6 tahap yaitu, concept, design, collecting material, assembly, testing dan distribution. Hasil dari penelitian ini yaitu aplikasi mobile dan desktop yang berisikan materi kalimat fi'liyyah dan bisa menjadi alternatif belajar mata pelajaran Bahasa arab. Aplikasi tersebut kemudian diuji dengan metode pengujian blackbox, pengujian angket dan pengujian pretest dan posttest.
\end{abstract}

Kata kunci: Aplikasi, Android, Blackbox, Bahasa arab

\section{PENDAHULUAN}

Bahasa arab (al-lughah al-'Arabiyyah, atau secara ringkas 'Arabi) merupakan salah satu bahasa Semit Tengah, yang termasuk dalam rumpun bahasa Semit dan berkerabat dengan bahasa Ibrani dan bahasa-bahasa Neo Arami. Bahasa Arab memiliki lebih banyak penutur daripada bahasa-bahasa lainnya dalam rumpun bahasa Semit. Ia dituturkan oleh lebih dari 280 juta orang. Sebagai bahasa pertama, yang mana sebagian besar tinggal di Timur Tengah dan Afrika Utara (Rahmad, 2017).

Pelaksanaan proses pembelajaran melibatkan beberapa komponen yang saling mempengaruhi, diantaranya adalah komponen guru, peserta didik, tujuan pembelajaran, materi, metode pembelajaran, media edukasi, dan evaluasi. Keberhasilan pembelajaran sangat ditentukan oleh dua komponen yakni metode dan media edukasi. Dua komponen ini menunjang penyampaian materi kepada peserta didik. Penggunaan metode pembelajaran tidak akan terlepas dari media edukasi. Media edukasi mampu mengubah materi yang rumit menjadi ringan dan mampu mengubah materi yang terlihat abstrak menjadi lebih konkret dan lebih mudah diingat. Hal terpenting dalam penggunaan media edukasi mampu meningkatkan motivasi belajar siswa sehingga tidak hanya guru yang aktif, siswapun aktif di dalam proses pembelajaran.
Permasalahannya yaitu pembelajaran yang digunakan masih menggunakan metode konvensional. Siswa tidak fokus ke pelajaran saat mengunakan metode konvensional. Sekolah minim media pembelajaran dan guru belum mampu membuat media edukasi tersebut.

Penelitian pertama terkait media edukasi pernah dilakukan oleh Husaini (2013), yang berjudul "Pembuatan Media Edukasi Ayo Bermain Huruf Hijaiyah Pada TPA An-Nur Daleman" dan penelitian kedua terkait media pembelajaran juga sudah dilakukan oleh Nuranggraini (2012), yang berjudul "Perancangan Media Pembelajaran Ilmu Nahwu Berbasis Multimedia". Penelitian pertama memiliki kelebihan yaitu media tersebut dapat menggantikan media iqro' yang selama ini di gunakan untuk mengajar. Penelitian kedua materi yang mencakup nahwu sudah tercakup di perancangan media pembelajaran ilmu nahwu berbasis multimedia. Penelitian pertama hanya menghasilkan materi huruf hijaiyyah yang ruang lingkupnya iqro'. Sedangkan penelitian yang kedua tidak ada evaluasi/latihan soal pada perancangan media ilmu nahwu berbasis multimedia itu.

Perbedaan dengan penelitian sebelumnya, yaitu penelitian ini merancang sebuah aplikasi media pembelajaran yang konsepnya media edukasi. Di dalam aplikasi ini 
terdapat materi kalimah fu'liyyah, fi'il, fa'il, maf'ul dan latihan soal atau evaluasi.

Harapannya dengan aplikasi ini siswa MI Nyatnyono 01 mampu meningkatkan prestasi dan menjadi alternatif untuk membantu siswa belajar materi Fi'liyyah menjadi lebih menyenangkan, mudah diingat dan mampu meningkatkan motivasi belajar siswa

\section{TINJAUAN PUSTAKA}

\subsection{Multimedia}

Menurut KBBI multimedia adalah penyedian informasi pada komputer yang menggunakan suara, grafika, animasi, dan teks . Husain (2013) berpendapat multimedia adalah pemanfaatan komputer untuk mengabungkan teks, grafik, audio, gambar bergerak (video dan animasi) menjadi suatu kesatuan dengan link dan tool yang tepat sehingga memungkinkan pemakai multimedia dapat melakukan navigasi, berinteraksi, berkreasi, dan berkomunikasi.

\subsection{Media interaktif}

Multimedia interaktif adalah pemanfaatan computer untuk pengabungan teks, grafik, audio, gambar bergerak (video dan animasi) dengn menggabungkan link dan tool yang memungkinkan pemakai melakukan berinteraksi, berkreasi dan berkomunikasi. (Sarwiko, 2010)

\subsection{Unity 3d}

Unity adalah sebuah game enginer yang berbasis cross-platfom yang dibuat oleh Unity Teknologi. Unity digunakan untuk membuat sebuah game yang bisa digunakan pada sebuah perangkat computer, ponsel pintar android, iphone, PS 3, dan X-BOX (Syarifah dan Suheri, 2004).

\section{METODE PENELITIAN}

Untuk melakukan penelitian ini penulis menggunakan metode pengumpulan data melalui prosedur pengumpulan data cara studi literatur data. Studi literatur data sendiri untuk mengumpulkan data-data yang diperlukan dalam penelitian. Data-data dalam penelitian dibagi menjadi dua kategori, yaitu data primer dan data sekunder. Sedangan untuk alat penunjang penulis menggunakan perangkat komputer dan aplikasi-aplikasinya

Dalam perancangan aplikasi ini, penulis mengimplementasikan metode pengembangan multimedia, metode pengembangan perangkat lunak yang meliputi 6 tahapan yaitu, concept, design, collecting content matrial, assembly, testing dan distribution.

\section{PERANCANGAN DAN IMPLEMENTASI \\ 4.1. Flowchart}

Flowchart digunakan untuk melakukan perencanaan proses, analisis proses, dan mendokumentasikan proses sebagai standar pedoman produksi. Flowchart juga digunakan sebagai peta kerja untuk mencegah terjadi kehilangan arah dan mempermudah pengambilan keputusan.

1. Flowchat aplikasi inovasi media edukasi bahasa arab

Flowchart pada Gambar 1. merupakan jalannya aplikasi "inovasi media edukasi bahasa arab" yang diawali dengan proses splash screen, loading, dan menuju menu utama. Pada menu utama sendiri terdapat enam tombol diantaranya materi, latihan, petunjuk, developer, setting dan keluar. Menu materi melihatkan beberapa tombol yaitu menu materi fi'il, menu materi fa'il, menu materi maf'ul dan menu materi kalimat. Menu latihan berisi tentang soal-soal latihan. Menu Petunjuk berisi tentang petunjuk pemakaian/penggunaan aplikasi. Menu Developer menunjukkan informasi pembuat aplikasi. Menu setting berisikan proses mematikan dan menghidupkan musik. Menu exit berguna untuk keluar dari aplikasi.

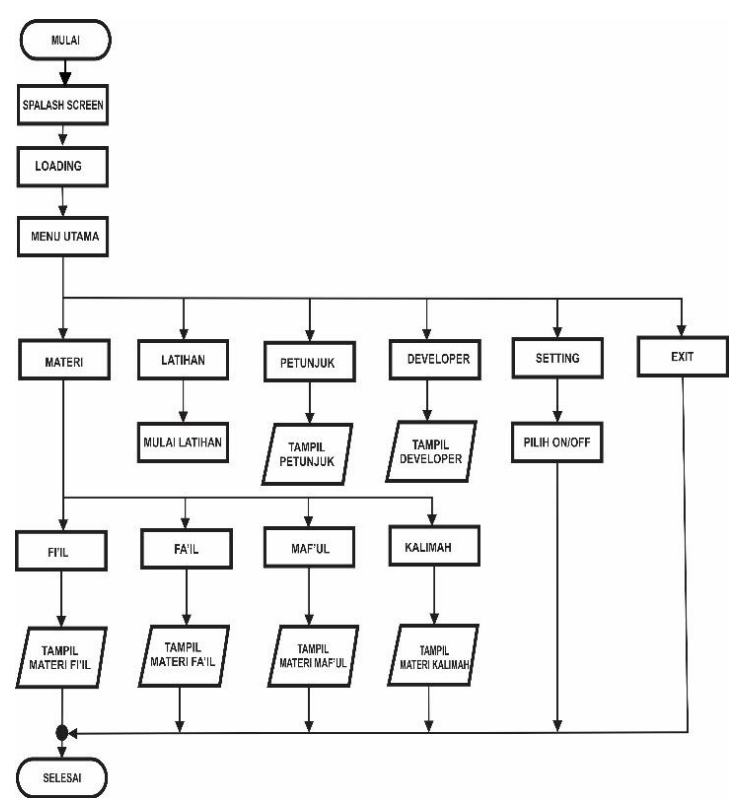

Gambar 1. Flowchart Aplikasi 


\section{Flowchart menu latihan}

Flowchart pada Gambar 2. merupakan flowchart latihan, setelah user memulai selanjutnya tampil halaman latihan soal-soal yang sudah disediakan, selanjutnya pilih soal, kemudian pilih jawaban, pada pilihan jawaban sudah disediakan jawaban apa yang dibutuhkan, tetapi susunan katanya berbeda. Selanjutnya dilakukan pengecekan, jika benar langsung dapat skor, tetapi jika salah kembali ke pilih soal. Setelah mendapat skor apakah mau di ulang atau selesai, jika diulang otomatis pilih soal lagi jika tidak otomatis selesai.

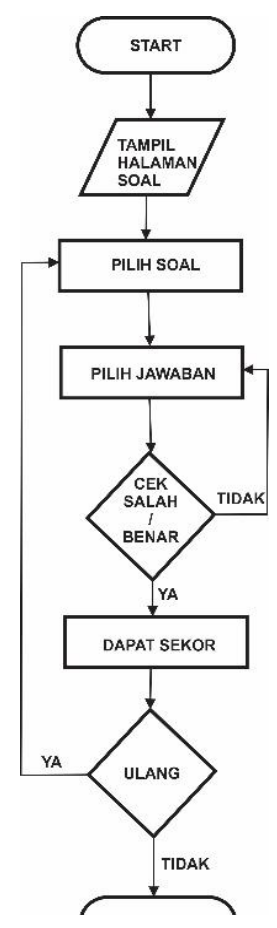

Gambar 2. Flowchart menu Aplikasi

\section{Use case diagram}

Use Case Diagram digunakan untuk mengetahui fungsi apa saja yang ada didalam sebuah sistem dan siapa saja yang berhak menggunakan fungsi fungsi tersebut. Yang ditekankan pada diagram ini adalah "apa" yang diperbuat sistem, dan bukan "bagaimana". Use Case Diagram mendeskripsikan interaksi antara satu atau lebih aktor dengan sistem yang akan dibuat, seperti yang ditunjukkan pada Gambar 3.

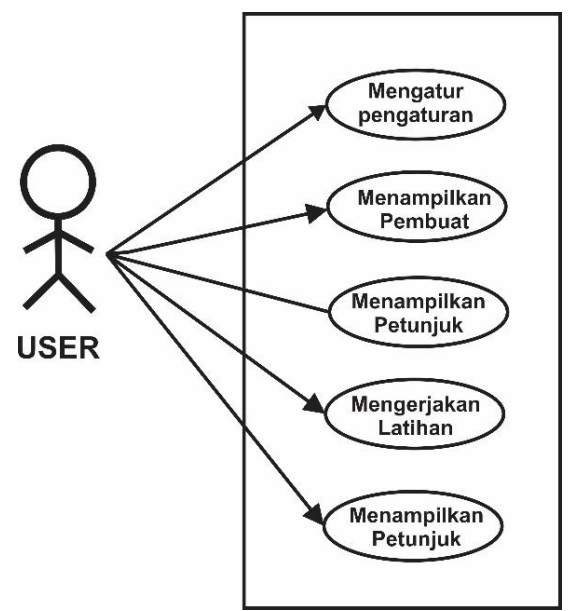

Gambar 3. Use Case Diagram

\section{HASIL DAN PEMBAHASAN}

\subsection{Hasil}

Pada bagian ini akan di tampilkan hasil dari implementasi aplikasi inovasi media pembelajaran bahasa arab dengan menggunakan software Unity 3D sebagai media pembelajaran.

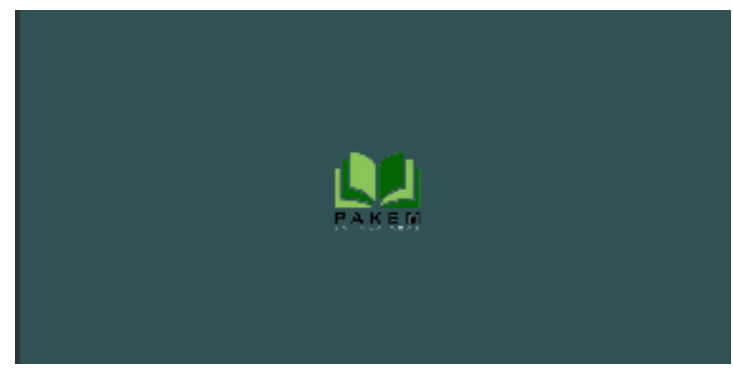

Gambar 4. Splash Screen

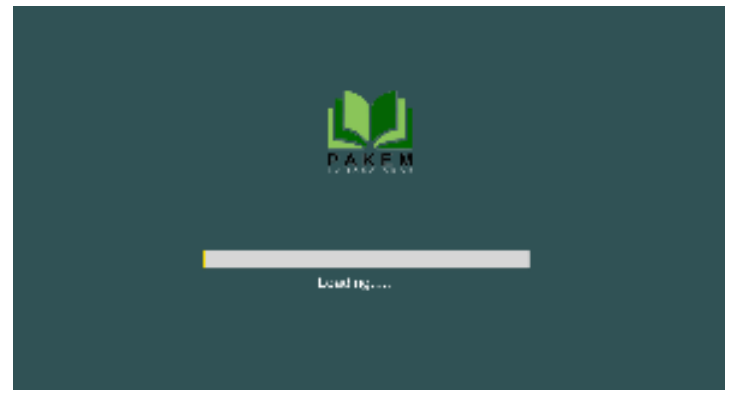

Gambar 5. Halaman Loading 


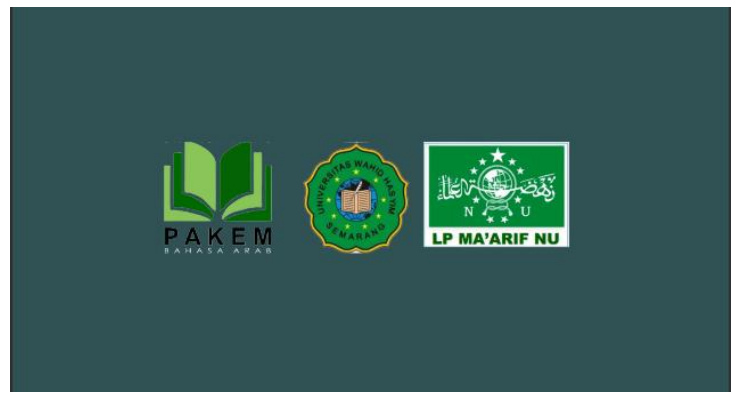

Gambar 6. Halaman logo

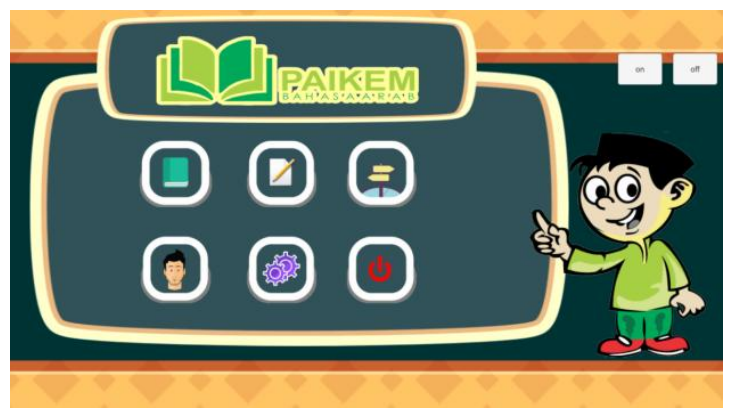

Gambar 7. Halaman menu utama

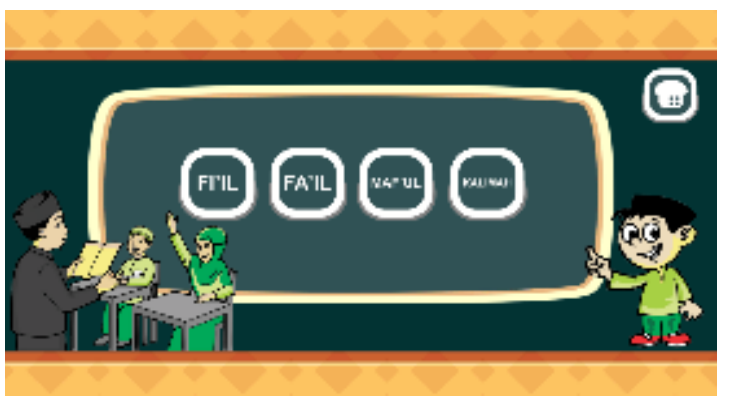

Gambar 8. Halaman menu materi

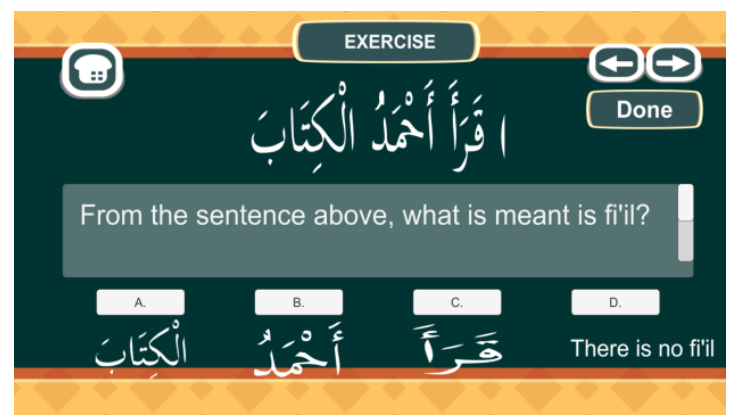

Gambar 9. Halaman menu latihan

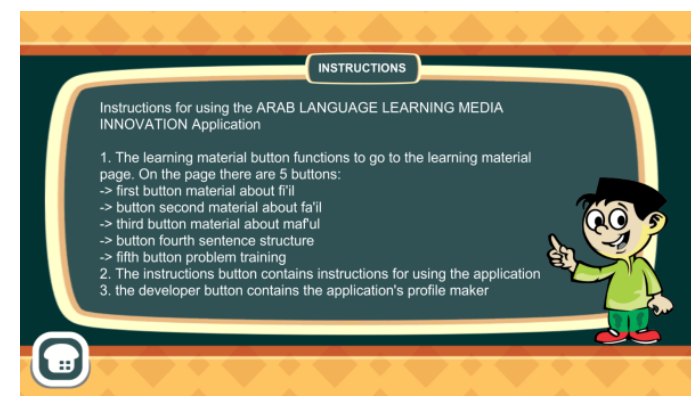

Gambar 10. Halaman petunjuk

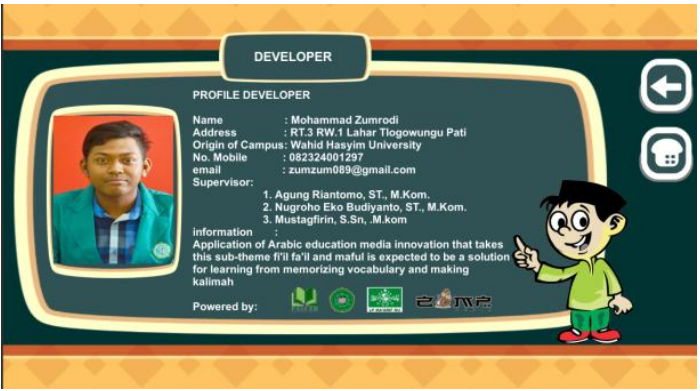

Gambar 11. Halaman developer

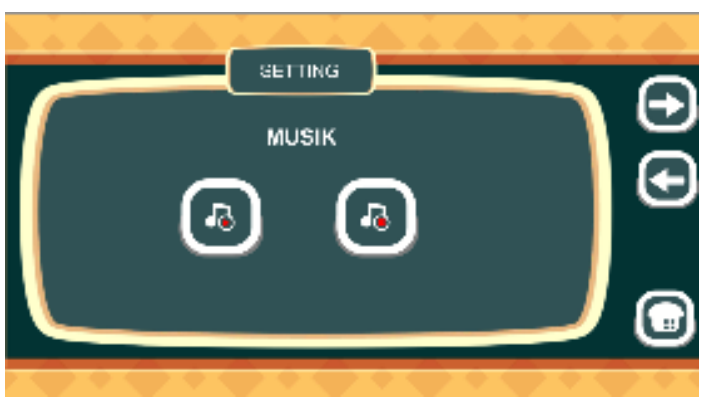

Gambar 12. Halaman setting

\subsection{Pengujian BlackBox}

Sesuai dengan langkah pengujian sistem menggunakan black box yang bertujuan untuk mengetahui apakah fungsi dari input dan output pada aplikasi telah sesuai dengan apa yang diharapkan.

Tabel 1. Tabel pengujian BlackBox

\begin{tabular}{llll}
\hline No & Tombol & Fungsi & Hasil \\
\hline & Halaman Menu Utama & \\
\hline 1 & Materi & Menuju Ke & Berhasil \\
& & Halaman & \\
& & Materi & \\
\hline 2 & Latihan & Menuju & Berhasil \\
& & Kehalaman & \\
& & Latihan & \\
\hline 3 & Petunjuk & Menuju & Berhasil \\
& & Kehalaman & \\
& & Petunjuk & \\
\hline 4 & Developer & Menuju & Berhasil \\
\hline
\end{tabular}


INFORMATIKA DAN RPL, Vol. 2, No. 1, Maret 2019, Hal. 42-48

ISSN 2656-2855

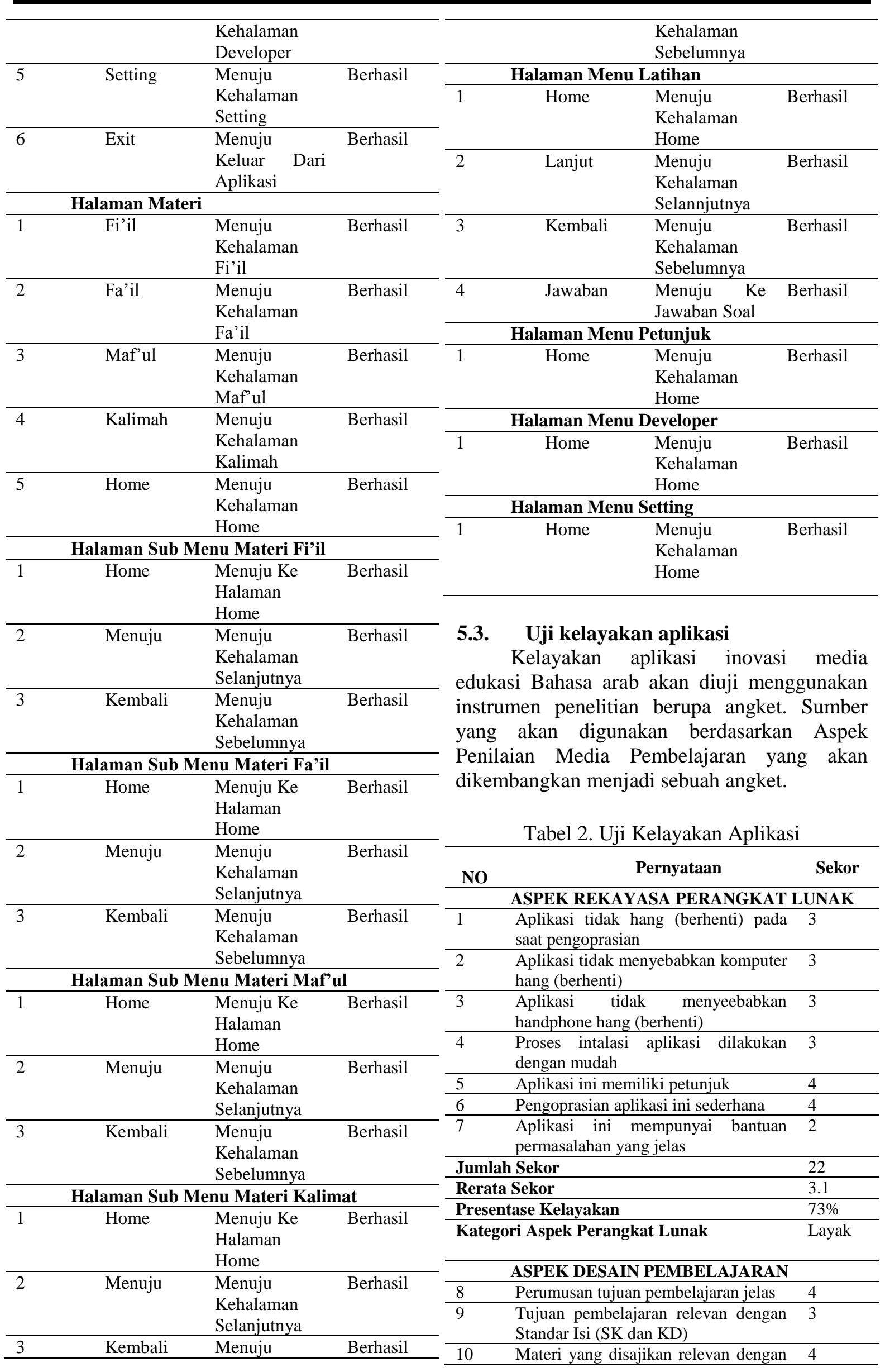




\begin{tabular}{|c|c|c|}
\hline \multicolumn{3}{|c|}{ tujuan pembelajaran } \\
\hline 11 & Materi yang disajikan mutakhir & 3 \\
\hline 12 & $\begin{array}{l}\text { Pembahasan contoh-contoh dalam } \\
\text { media mudah dipahami }\end{array}$ & 4 \\
\hline 13 & Soal dirumuskan dengan jelas & 3 \\
\hline 14 & Kunci jawaban sesuai dengan soal & 3 \\
\hline 15 & $\begin{array}{l}\text { Adanya umpan balik terhadap hasil } \\
\text { evaluasi }\end{array}$ & 2 \\
\hline 16 & $\begin{array}{l}\text { Evaluasi konsisten dengan tujuan } \\
\text { pembelajaran }\end{array}$ & 3 \\
\hline 17 & $\begin{array}{l}\text { Bahasa yang digunakan untuk } \\
\text { menyampaikan materi komunikatif }\end{array}$ & 3 \\
\hline 18 & $\begin{array}{l}\text { Siswa lebih aktif dalam melakukan } \\
\text { kegiatan belajar }\end{array}$ & 4 \\
\hline \multicolumn{2}{|c|}{ Jumlah Sekor } & 36 \\
\hline \multicolumn{2}{|c|}{ Rerata Sekor } & 3.27 \\
\hline \multicolumn{2}{|c|}{ Presentase Kelayakan } & $90 \%$ \\
\hline \multicolumn{2}{|c|}{ Kategori Aspek Perangkat Lunak } & Layak \\
\hline \multicolumn{3}{|c|}{ ASPEK KOMUNIKASI VISUAL } \\
\hline 19 & $\begin{array}{l}\text { Kreatif dalam menuangkan ide dan } \\
\text { gagasan }\end{array}$ & 4 \\
\hline 20 & $\begin{array}{l}\text { Tampilan yang digunakan dalam } \\
\text { aplikasi menarik }\end{array}$ & 3 \\
\hline \multicolumn{2}{|c|}{ Jumlah Sekor } & 7 \\
\hline \multicolumn{2}{|c|}{ Rerata Sekor } & 3.5 \\
\hline \multicolumn{2}{|c|}{ Presentase Kelayakan } & $74 \%$ \\
\hline \multicolumn{2}{|c|}{ Kategori Aspek Perangkat Lunak } & $\begin{array}{l}\text { Sangat } \\
\text { Layak }\end{array}$ \\
\hline \multicolumn{2}{|c|}{ Jumlah Keseluruhan Sekor } & 65 \\
\hline \multicolumn{2}{|c|}{ Rata-Rata Keseluruhan Sekor } & 3.25 \\
\hline \multicolumn{2}{|c|}{ Presentase Kelayakan Keseluruhan } & $6.25 \%$ \\
\hline \multicolumn{2}{|c|}{ Kategori } & Layak \\
\hline
\end{tabular}

\subsection{Uji efektifitas}

Sesuai dengan langkah uji efektifitas Penelitian penulis menggunakan pre test dan post test. yang bertujuan untuk mengetahui apakah ada prestasi peningkatan yang ada sebelum dan sesudah di uji cobakan di siswa. Pada pengujian ini terdapat 2 kelompok siswa. kelompok A menggunakan media pembelajaran konfensional atau dengengan metode ceramah. Sedangkan kelompok B menggunakan metode media edukasi.

Tabel 3. hasil pengujian kelompok A

\begin{tabular}{lcc}
\hline Aktivitas & Pre test & Post test \\
\hline Total Nilai & 470 & 820 \\
Rata-rata & 33.5 & 58.5 \\
Kenaikan hasil & 25 & \\
N-Gain & $0.37 \%$ & \\
\hline
\end{tabular}

Tabel 4. Pengujian kelompok B

\begin{tabular}{lcc}
\hline Aktivitas & Pre test & Post test \\
\hline Total Nilai & 485 & 1220 \\
Rata-rata & 34.64 & 87.1 \\
Kenaikan hasil & 52.5 & \\
N-Gain & $1.5 \%$ & \\
\hline
\end{tabular}

Tabel 5. data hasil pencapaian

\begin{tabular}{lcc}
\hline Aktivitas & \multicolumn{1}{l}{$\begin{array}{l}\text { Hasil } \\
\text { kelompok A }\end{array}$} & $\begin{array}{l}\text { Hasil } \\
\text { kelompok B }\end{array}$ \\
\hline $\begin{array}{l}\text { Hasil rata- } \\
\text { rata }\end{array}$ & 25 & 52.5 \\
N-Gain & & \\
\hline
\end{tabular}

\section{KESIMPULAN DAN SARAN \\ 6.1. Kesimpulan}

Berdasarkan hasil penelitian ini, peneliti mendapat kesimpulan sebagai berikut: 1. Dengan membuat Aplikasi Media Edukasi Kalimat Fi'liyyah Mata Pelajaran Bahasa Arab ini memberikan solusi yang bisa di terapkan terhadap media pembelajaran yang di berikan pada anak-anak kelas 6 MI Nyatnyono 01.

2. Aplikasi Media Edukasi Kalimat Fi'liyyah Mata Pelajaran Bahasa Arab menyajikan kosakata-kosakata yang lebih berfokus ke materi dan juga pengenalan pembuatan kalimat dengan melihat struktur kalimat yang benar.

3. Hasil uji kelayakan aplikasi memperoleh nilai rata-rata yang masuk dalam rentang ( $\mathrm{X}$ $\leq 3.4$ ) dengan kategori layak. Sehingga tingkat kelayakan media pembelajaran berdasarkan validasi praktisi pembelajaran (guru) masuk dalam kategori layak. Sedangkan uji efektifitas mendapatkan kenaikan sebesar $75 \%$ minat belajar siswa menggunakan media pembelajaran tersebut.

\subsection{Saran}

Berdasarkan penelitian ini, saran untuk penelitian selanjutnya adalah pengembangan aplikasi media edukasi sebagai media belajar untuk mempermudah siswa dalam belajar bahasa arab lebih sempurna. Pengembangan tersebut dengan lebih memperbanyak materi beserta soal latihan yang ada pada media edukasi ini

\section{DAFTAR PUSTAKA}

Husaini, F. (2013). Pembuatan Media Edukasi Ayo Bermain Huruf Hijaiyah Pada Tpa An-Nur Daleman. Seminar Riset Unggulan Nasional Informatika Dan Komputer Fti Unsa

Nuranggraini, W. (2012). Perancangan Media Pembelajaran Ilmu Nahwu Berbasis Multimedia.Naskah Publikasi Ilmiyah. 
Rahmad Iswanto. (2017). Pembelajaran Bahasa Arab Dengan Pemanfaatan Teknologi. Arabiyatuna. Vol. 1, No 2. Sekolah Tinggi Agama Islam Negri (Stain)

Sarwiko Dwi. (2010). Pengembangan Media Pembelajaran Berbasis Multimedia Interaktif Menggunakan Macromedia Director Mx (Studi Kasus Mata Kuliah Pengolahan Citra Pada Jurusan S1 Sistem Informasi). Gunadarma. Vol 1.

Syarifah, D. dan Suheri, A. (2014). Pengembangan Visual Portofolio Digital Berbasis Augmented Reality Menggunakan Kartu Tanda Penduduk Dan Android. Media Jurnal Informatika Vol.6. Universitas Suryakencana (Unsur) 